UDC 80.801.8.82

DOI https://doi.org/10.24919/2308-4863/40-3-17

\author{
Yuliia SAVINA, \\ orcid.org/0000-0002-9955-0760 \\ Candidate of Philological Sciences, Associate Professor, \\ Associate Professor at the Department of Translation \\ Dnipro University of Technology \\ (Dnipro, Ukraine) savinajulia@ukr.net
}

\title{
USE OF TRANSFORMATIONS FOR ACHIEVING ADEQUACY WHEN REPRODUCING IRONY IN TRANSLATION OF ENGLISH LITERARY TEXTS INTO UKRAINIAN
}

The article describes the specifics of applying translation transformations for achieving adequacy when reproducing irony in translation of English literary texts into Ukrainian. The relevance of the current research is conditioned by the fact that the irony is context-dependent phenomenon, and its understanding depends of the form of the utterance. The aim of the research is to determine the specifics of applying translation transformations for achieving adequacy of representing irony in the course of translation of English literary texts into Ukrainian. In the course of the study, irony is defined as an expressive means in the texts of literary discourse; the problems in translating English irony into Ukrainian are analysed; and the characteristic features of applying translation transformations as means of representing irony in translation are determined. The conducted research allowed concluding that irony, along with humor, is one of the means of relaxation through comic effect. The authors of the literary texts use irony to put themselves and their characters above the circumstances, difficulties, and all the chaos that exists in life. As understanding irony by the reader greatly depends of the context in which it is used, and the context can vary from phrase to the whole literary work, and the reader has to use one's own cognitive abilities in this process, as well as because of the fact that comprehension of irony is complicated in the situation of intercultural communication, especially in the cases when the literary text is translated, the translator needs to pay special attention to representation of irony when rendering such texts. One of the effective tools in representing irony in translation is the application of translation transformations, mainly modulation, replacements, addition and total rearrangement. The application of such translation transformations leads to preserving the unexpectedness and illogicality of the statement used by the author in a particular context, so the reader of the translation is fully aware of the contrast between what was expected and what was said which ensures adequacy of irony translation.

Key words: irony, literary work, Jane Austen, Pride and Prejudice, translation, translation transformations.

\section{Юлія САВІНА, \\ orcid.org/0000-0002-9955-0760 кандидат філологічних наук, доцент, дочент кафедри перекладу Національного технічного університету «Дніпровська політехніка» (Дніпро, Україна) savinajulia@ukr.net \\ ВИКОРИСТАННЯ ТРАНСФОРМАЦЙ ДЛЯ ДОСЯГНЕННЯ АДЕКВАТНОСТІ У ВІДТВОРЕННІ ІРОНІЇ ПІД ЧАС ПЕРЕКЛАДУ АНГЛІЙСЬКОГО ХУДОЖНЬОГО ТЕКСТУ УКРАЇНСЬКОЮ МОВОЮ}

У статті описано особливості застосування перекладаџьких трансформащій для досягнення адекватності під час відтворення іронії у перекладі англійських художніх текстів украӥнською мовою. Актуальність иьього дослідження зумовлена тим, щу іронія є контекстуально залежним явищем, $і$ ії розуміння залежить від форми висловлювання. Метою дослідження є визначення особливостей застосування перекладацьких трансформацій для досягнення адекватності передачі іронії у процесі перекладу англомовних літературних текстів українською мовою. У прочесі дослідження визначено іронію як виразний засіб у текстах художнього дискурсу, проаналізовано проблеми перекладу англійської іронії украӥнською мовою та визначено характерні особливості застосування перекладацьких трансформачій як засобів відображення іронії в перекладі. Проведене дослідження дало змогу дійти висновку, що іронія, поряд із гумором, є одним із засобів розслаблення через створення комічного ефекту. Автори художніх текстів використовують іронію, щоби поставити себе та свойх героїв над обставинами, труднощали та всім хаосом, який існує у житті. Оскільки розуміння читачем іронї значно залежить від контексту, в якому вона використовується, $і$ контекст може варіюватися від фрази до всього літературного твору, а читач повинен використовувати власні пізнавальні здібності в цъьому процесі, а також через той факт, щцо розуміння іронії ускладнюється в ситуації міжкультурної комунікації, особливо в тих випадках, коли перекладається художній текст, перекладачеві необхідно звертати особливу увагу на передачу іронї під час 
відтворення таких текстів. Одним із ефективних інструментів відтворення іронії у перекладі є застосування перекладацьких трансформацій, головним чином модуляиії, граматичних замін, додавання та цілісного перетворення. Застосування таких перекладацьких трансформацій приводить до збереження несподіваності та нелогічності висловлювання, використаного автором у певному контексті, тому читач перекладу повністю усвідомлює протиставлення очікуваного та сказаного, що забезпечує адекватність передачі іронії в перекладі.

Ключові слова: іронія, художній твін, Джейн Остен, «Гордість і упередженість», переклад, перекладацькі трансформачїі.

Formulation of the problem. The comic in humorous culture is the heritage of the author's consciousness reflecting national and cultural specificity of the country. It is caused by social contradictions, and its value is in exposing and criticizing. The character of a person is manifested in what he finds funny. Irony as element of the comic is critical, analytical and intellectual in nature. Its pragmatic influence is effective because it is able to express strong emotions in the addressee.

Irony is often used in literature to produce a comic effect. This may also be combined with satire. For instance, an author may facetiously state something as a well-known fact and then demonstrate through the narrative that the fact is untrue. Irony is thus an effective way for an author to express ideas of what she thinks describes the society in which she lives. Irony can explore the differences between what a society or person says or does and how they actually live. A society which claims to value truth and justice, but actually tolerates or encourages lying and injustice is ironic.

Translation of irony is one of the most researched areas of Translation Studies. Although there are general features of such a translation, reproduction of humorous elements has its own specifics for each language. The comic has a fairly clear national characteristics which are manifested in the choice of its subject, and in various "technologies" to create comic effect. This specificity is not always clear, because the phenomena of human culture are never subject to final formalization, so reproducing irony is still a relevant issue in Translation Studies.

Analysis of the researches. Irony has long been known by the scholars and artists. Gibbs (1994: 364) writes that the word irony comes from the Greek term eironia, which describes the main characteristic of the stock characters (the "ironical man") in the early Greek plays. Abrams (1999: 135) adds that in Greek comedy the character called the "eiron" was a dissembler, who characteristically spoke in understatement and deliberately pretended to be less intelligent than he was, yet triumphed over the "alazon" - the self-deceiving and stupid braggart.

However, the issue of the essence of irony, its linguistic nature, the mechanisms of creating ironic content still remain poorly studied and debatable. Irony is interpreted in a broad aspect (lexical and stylistic means, stylistic feature of the text, general semiotic and aesthetic category, etc.), as well as the implementation of irony at different levels: in microcontext (word or phrase), macrocontext (text fragment) and megacontext of the whole work) (Смирнова, 2002: 185).

The concept of irony (from the Greek eironeia - literally pretending, cunning, ridicule, hidden ridicule) is interpreted as: 1) subtle, hidden ridicule, mockery; 2) feature of style which is the discrepancy between the direct meaning of the statement (word) and its true (hidden) meaning, which is easy to guess (Дзеверін, 1990: 334).

Linguistic and literary dictionaries (Кузьменко, 1997) and textbooks on stylistics (Гальперин, 1977) define irony as a trope, the main feature of which is a double meaning, where the true is hidden or contradicts (opposes) the visible. Instead, foreign authors in their studies on the comic consider irony as a category of the comic, without focusing on the concept of satire (Drabble, 2004). Irony in the conventional sense is interpreted as circumlocution. "Irony, in contrast to deception, not only hides the truth, but also expresses it, only in a different way," V. Shestakov writes (Шестаков, 1983: 227).

Although there are numerous researches on the specifics of representing irony in translation (for example, (Матюхина, 2004; Фесенко, 2005), there is still a need to determine the specific ways of translating the ironical utterances used by the authors of the literary texts as correct representation of irony is crucial for understanding the characters and the author's intention in general.

Aim. The analysis of the current state of the research in the sphere of translating irony allows to formulate the aim of the article as follows: to determine the specifics of applying translation transformations for achieving adequacy of representing irony in the course of translation of English literary texts into Ukrainian. Accordingly, the research: 1) defines irony as an expressive means in the texts of literary discourse; 2) analyses the problems in translating English irony into Ukrainian; 3) determines the characteristic features of applying translation transformations as means of representing irony in translation.

Presentation of the research material. Irony is a method of funny or subtle sarcastic expression, when the meaning of the words used is the direct 
opposite of their usual meaning (Yan, 2006: 14-15). It is an expression of ridicule by using a word in a meaning directly opposite to its basic meaning, and with directly opposite connotations, the pretense of praise, which is actually condemnation, I.V. Arnold says. The oppositeness of the connotation is realised in the change of the evaluative component from positive to negative one, affectionate emotion to ridicule, in the use of words with sublime and poetic colouring in relation to trivial and vulgar objects to show their insignificance (Арнольд, 2002: 86).

Irony, as noted in the study by N.F. Nepiyvoda, is a "sign of the times" that in the late 20th century penetrated into all spheres of public life. Among the reasons of using irony, the author mentions primarily the information explosion, on the one hand, and limited human ability to process a huge flow of information, on the other (Непийвода, 2004: 137). "In such conditions," the researcher concludes, "a person needs relaxation, and what, if not irony / humor, can effectively fulfill this role?" (ibid.: 137). Therefore, attention is focused on another important function performed by irony in the modern text - relaxation, relief.

The appeal to irony in art, literature, and other areas of life is caused by the desire of the person to put oneself above the circumstances, difficulties, and all the chaos that exists in the life. An ironic attitude to reality helps, if not to find an orderly explanation of what is happening, at least to assert the "hopelessness" of human search and effort (Маточкина, 2009: 291). As S. Kierkegaard accurately noted, "as a negation, irony is the way - not the truth, but only the way to it" (Киркегор, 1993: 188).

The context, in which there is irony, varies from a minimum - a phrase - to the context of the whole book. The effect of irony depends on the unexpectedness and illogicality of the statement used by the author in a particular context. The reader is fully aware of the contrast between what was expected and what was said. This contrast of meanings very often creates a humorous effect (Гафиатулина, 2004: 16).

Irony is usually used to convey negative content. Therefore, only positive concepts can be used in their vocabulary meanings. Contextual meaning always conveys the denial of positive features implemented in the dictionary meaning (Гальперин, 1977: 134). The right choice of the means of implementation of irony is one of the key points of its effectiveness. Yu. I. Bilodid rightly remarked on this subject: "By selecting vocabulary belonging to different and often incompatible lexical and thematic groups, and creating [...] bright stylistic devices, the author achieves and increases the expressiveness of the text [...], sets the general ironic tone of the whole work" (Білодід, 1981: 71).
The role of markers of irony is primarily the context. The realisation of ironic content in a work of art is inextricably linked to the ability of language units to acquire connotative and associative meaning in context. Thus, the ironic meaning depends on the way the text is organised (Циркунова, 2012: 388).

In the context of bilingual communication, the process of creating and transmitting ironic codes becomes even more complex and, therefore, prone to communication failures as there is another link between the author and the reader - the translator. In the first stage of interpretation of the statement, the latter the recipient, and his understanding of the illocutionary meaning laid down by the author determines whether the original reference to the recipient and thus the author achieves the pragmatic goal. In the second stage of recoding an ironic utterance, the success of the transmission of irony depends on the translator's ability to find equivalent units in the target language and to convey the locutive and implicit meaning of the utterance as close to the original as it is possible (Матюхина, 2004: 56).

Despite a deep penetration of the translator into the author's intent, it is not always possible for the translator to achieve equivalence of the source text and target text in terms of their artistic influence on the reader, transferring of the specific form and content. Translational transformation, which are seen as the main method of transition, have mostly formal and semantic significance (Фесенко, 2005: 103).

So, translation of irony requires transformations on the different language levels which allows to correctly represent the comic effect created by the ironical expression. For example, wide use of the transformation of modulation allows to stress on the ironical nature of the utterance as the correct choice of words is very important for perceiving irony: "Don't keep coughing so, Kitty, for Heaven's sake! Have a little compassion on my nerves. You tear them to pieces." "Kitty has no discretion in her coughs," said her father; "she times them ill" (Austen, 2004: 5) - «I чого ти так розкашлялася, Kітті?! Замовкни, заради Бога! Пожалій хоч трохи мой нерви. Ти ж їх просто рвеш на шматки.» «Кітmi кашляє без належної до вас поваги, - сказав iï батько, - вона робить це явно невпопад» (Остен, 2018: 3). Here, rendering discretion as повага allows to represent the idea that one character's coughs are intended to insult another one, which is the core of irony in the presented example.

However, most transformations used for representing irony in translation belong to the grammatical level of the language. These are replacements and addition. 
Reproducing irony in translation often requires the application of grammatical replacements as they are caused by the morphological and grammatical differences between English and Ukrainian. In particular, in the following text fragment the character in the novel Pride and Prejudice by Jane Austen mocks his wife because she talks about her nerves as about something separate from her: "Mr. Bennet, how can you abuse your own children in such a way? You take delight in vexing me. You have no compassion for my poor nerves." "You mistake me, my dear. I have a high respect for your nerves. They are my old friends. I have heard you mention them with consideration these last twenty years at least" (Austen, 2004: 4). As a result, he speaks about his wife's nerves as about independent family member, i.e., person which creates the effect of irony. In translation, subject and predicate in the husband's utterance are changed in order to make the sentence suitable to the norms of the target language: «Mістере Беннет, як ви можете так зневажливо відзиватися про власних дітей? Чи вам просто подобається навмисне дратувати мене? Ви зовсім не поважаєте мої слабкі нерви.» "Серденько, ви неправильно мене зрозуміли. Ваші слабкі нерви викликають у мене надзвичайну повагу. Вони-мої давні друзі. Останні двадцять років я тільки й чую, як ви з теплотою згадуєте про них» (Остен, 2018: 2).

Addition allows to increase the expressivity of utterance thus creating even more absurd situation than in the source language. In particular, in the following example: It is a truth universally acknowledged, that a single man in possession of a good fortune, must be in want of a wife (Austen, 2004: 1) Загальновизнаною істиною $є$ те, що одинак - $\underline{\boldsymbol{m a}}$ ще й при грубеньких грочах - неодмінно мусить прагнути одружстися (Остен, 2018: 1), addition of the component та ще and неодмінно stresses on the necessity of the connection between the possession of money and the need of wife as the irony in this case is in the fact that not the man in possession of money really wants to marry but the society, especially potential wives, want it.

There are also lexical and grammatical transformations that are important for adequate rep- resentation of irony in translation. Particularly, the transformation of total rearrangement is used in the following example: "Your examination of Mr. Darcy is over, I presume," said Miss Bingley; "and pray what is the result?" "I am perfectly convinced by it that Mr. Darcy has no defect. He owns it himself without disguise" (Austen, 2004: 36) - «Гадаю, ви вже закінчили своє дослідження містера Дарсі? -запитала міс Бінглі. - I якого ж висновку дійшли?» «Я прийшла до переконання, щуо містер Дарсі - особистість абсолютно бездоганна. Здається, він і сам цього не приховує» (Остен, 2018: 35). The ironic nature of the utterance is in the fact that the main character exaggerates the positive features of Mr. Darcy thus implying that he pretends to look too perfect. In translation, the phrase $\mathrm{He}$ owns it himself without disguise is completely paraphrased as Здається, він і сам иьвого не приховує which allows to preserve ironic meaning rather than the form of the utterance.

Conclusions. Irony is thus seen, along with humor, as one of the means of relaxation through comic effect. Using irony, the author of the literary text can fulfill the desire to put oneself above the circumstances, difficulties, and all the chaos that exists in the life. The context where irony is used can vary from one phrase to the whole text, and interpretation of irony in the literary text greatly depends on the cognitive abilities of the reader and his or her ability to understand the context. The ironic meaning depends on the way the text is organised. Comprehension of irony is complicated in the situation of intercultural communication, especially in the cases when the literary text is translated, so the translator needs to pay special attention to representation of irony when rendering such texts. The results of the research demonstrates that the basic translation transformations used for representing irony in translation are modulation, replacements, addition and total rearrangement.

The conducted research has wide prospects, in particular, there is a need to understand the cognitive and discursive nature of irony, as well as further deep comprehensive analysis of the specifics of representing irony when translating literary texts.

\section{BIBLIOGRAPHY}

1. Арнольд И. В. Стилистика. Современный английский язык. 4-е изд., испр. и доп. Москва: Флинта: Наука, 2002. $384 \mathrm{c}$.

2. Білодід Ю.І. Засоби іронії в сучасному політичному романі. Мовознавство. 1981. № 4. С. 71-73.

3. Гальперин И.Р. Стилистика английского языка. Москва: Высшая школа, 1977. 332 с.

4. Гафиатулина Ю.О. English Stylistics. Павлодар: ПГУ им. С. Торайгырова, 2004. 76 с.

5. Киркегор С. О понятии иронии. Пер. А. Коськовой, С. Коськова. Логос. 1993. № 4. С. 176-198.

6. Кузьменко В.І. Словник літературознавчих термінів. Київ: Український письменник, 1997. 230 с.

7. Маточкина А.М. Особенности перевода иронии в англоязычной прессе. Нова філологія. 2009. № 34. С. 290 -295. 
8. Матюхина А.Н. Речевая форма, языковые средства и приемы иронии на материалах текстов газетно-публицистического стиля. Вопросы филологических наук. 2004. № 6. С. 56-63.

9. Непийвода Н.Ф. Стилістичний аспект масової комунікації. Наукові записки Інституту журналістики. Том V. Факультет соиіології та психології. Київ: Київський національний університет імені Тараса Шевченка, 2004. C. $133-140$.

10. Остен Дж. Гордість і упередженість. Переклад В. Горбатька. Харків: Фоліо, 2018. 350 с.

11. Смирнова Н. Н. Путь иронии в XX веке: от отрицания абсолютной серьезности к самоотрицанию. Bonросы филологии. 2002. № 3 (12). С. 52-60.

12. Українська літературна енциклопедія: в 5 т. Редкол.: І. О. Дзеверін (відп. ред.) та ін. Київ: «Українська радянська енциклопедія» ім. М. П. Бажана, 1990. Т. 2. 576 с.

13. Фесенко Н.А. Комическое в тексте оригинала и переводе. Вестник ВГУ. Серия «Лингвистика и межкультурная коммуникация». 2005. № 2. С. 97-104.

14. Циркунова І.В. Відтворення іронії в перекладі з іспанської на української (на матеріалі творів іспаномовної літератури). Мовні і конщептуальні картини світу. 2012. № 42. Ч. 2. С. 385-391.

15. Шестаков В.П. Эстетические категории. Москва: Наука, 1983. 328 с.

16. Abrams M.H. A glossary of literary terms - 7th ed. Boston: Heinle \& Heinle, 1999. 456 p.

17. Austen J. Pride and Prejudice. New York: Simon and Schuster, 2004. 480 p.

18. Gibbs R. W. The poetics of mind: figurative thought, language, and understanding. New York: Cambridge University Press, 1994. $428 \mathrm{p}$.

19. The Oxford Companion the English Literature. Ed. by Drabble. Oxford: Oxford University Press, 2000. $1184 \mathrm{p}$.

20. Yan L. On figures of speech in Vanity Fair: A Thesis Submitted to Foreign Languages College Shanghai Normal University in Partial Fulfillment of the Requirements for The Degree of Bachelor of Arts in English Language. Shanghai, 2006. $31 \mathrm{p}$.

\section{REFERENCES}

1. Arnold I.V. Stilistika. Sovremennyi angliyskiy yazyk [Stylistics. Modern English language]. 4th ed., revised. Moscow: Flinta: Nauka, 2002. 384 p. [In Russian].

2. Bilodid Yu.I. Zasoby ironii v suchasnomu politychnomu romani [The means of irony in modern political novel]. Movoznavstvo, 1981, nr. 4, pp. 71-73 [In Ukrainian].

3. Galperin I. R. Stilistika angliyskogo yazyka [English Stlistics]. Moscow: Vysshaya shkola, 1977. 332 p. [In English].

4. Gafiatulina Yu.O. English Stylistics. Pavlodar: PGU im. S. Toraigyrova, 2004. 76 p. [In English].

5. Kirkegor S. O poniatii ironii [On the concept of irony]. Translated by A. Koskova, S. Koskov. Logos, 1993, nr. 4, pp. 176-198 [In Russian].

6. Kuzmenko V.I. Slovnyk literaturoznavchykh terminiv [Dictionary of Literary Terms]. Kyiv: Ukrayinskyi pysmennyk, 1994. 230 p. [In Ukrainian].

7. Matochkina A.M. Osobennosti perevoda ironii v angliyazychnoy presse [The specifics of rendering irony in English press]. Nova filolohiia, 2009, nr. 34, pp. 290-295 [In Russian].

8. Matyukhina A.N. Rechevaya forma, yazykovye sredstva i priyemy ironii na materialakh tekstov gazetno-publitsisticheskogo stilya [Speech form, language means and the methods of irony in the newspaper and publicist styles texts]. Voprosy filologicheskikh nauk, 2008, nr. 6, p. 56-63 [In Russian].

9. Nepyivoda N.F. Stylistychnyi aspekt masovoyi komunikatsii [Stylistic aspect of mass communication]. Naukovi zapusky Instytutu zhurnalistyky. Tom 5. Fakultet sotsiolohii ta psykhologii. Kyiv: Kyiivskyi natsionalnyi universytet imeni Tarasa Shevchenka, 2004, pp. 133-140 [In Ukrainian].

10. Osten Dzh. Hordist i uperedzhenist [Pride and Prejudice]. Translated by V. Horbatko. Kharkiv: Folio, 2018. 350 p. [In Ukrainian].

11. Smirnova N.N. Put ironii v 20 veke: ot otritsaniya absolutnoi seryeznosti k samootritsaniyu [The path of irony in 20th century: from denial of absolute seriousness to self-denial]. Voprosy filolohii, 2002, nr. 3 (12), pp. 52-60 [In Russian].

12. Ukrayinska literaturna encyklopediya: v 5 t. [Ukrainian literary encyclopedia: in 5 vols.). Editorial: I. O. Dzeverin et al. Kyiv: Ukrayinska radianska entsyklopediya im. M. P. Bazhana, 1990, vol. 2. 576 p. [In Ukrainian].

13. Fesenko N.A. Komicheskoye $\mathrm{v}$ tekste originala i perevode [The comic in the source text and translation]. Vestnik VGU. Seriya "Lungvistika i mezhkulturnaya kommunikatsiya", 2005, nr. 2, pp. 97-104 [In Russian].

14. Tsyrkunova I.V. Vidtvorennia ironii $v$ perekladi $z$ ispanskoyi na ukrayinsku (na materiali tvoriv ispanomovnoyi literatury) [Representing irony in translation from Spanish into Ukrainian (based on Spanish literature)]. Movni i kontseptualni kartyny svitu, 2012, nr. 42, p. 2, pp. 385-391 [In Ukrainian].

15. Shestakov V.P. Esteticheskiye kategorii [Aesthetic categories]. Moscow: Nauka, 1983. 328 p. [In Russian].

16. Abrams M.H. A glossary of literary terms - 7th ed. Boston: Heinle \& Heinle, 1999. 456 p. [In English].

17. Austen J. Pride and Prejudice. New York: Simon and Schuster, 2004. 480 p. [In English].

18. Gibbs R.W. The poetics of mind: figurative thought, language, and understanding. New York: Cambridge University Press, 1994. 428 p. [In English].

19. The Oxford Companion the English Literature. Ed. by Drabble. Oxford: Oxford University Press, 2000. 1184 p. [In English].

20. Yan L. On figures of speech in Vanity Fair: A Thesis Submitted to Foreign Languages College Shanghai Normal University in Partial Fulfillment of the Requirements for The Degree of Bachelor of Arts in English Language. Shanghai, 2006. 31 p. [In English]. 